Sultan Qaboos University Journal of Arts \& Social Sciences
جامعة السلطان قابوس مجلة الآداب والعلوم الاجتماعية

\title{
Why Do We Still Read George Orwell?
}

Neil McBeath

Assistant Language Lecturer

The Language Centre

Sultan Qaboos University

nmcbeath@squ.edu.om 


\title{
Why Do We Still Read George Orwell?
}

\author{
Neil McBeath
}

\section{Abstract:}

This paper approaches Orwell's writing from the perspective of the 21st century and asks whether Animal Farm, his satirical fable of the USSR, and the dystopian vision of Nineteen Eighty-Four remain relevant. It dismisses the suggestion that these last two novels can be regarded as the natural culmination of Orwell's earlier work, principally by examining these other writings demonstrates that there is no natural trajectory. The paper also refers to key dates in Orwell's life and comments on his career at those particular moments. Orwell remains relevant, the paper concludes, because the forces of oppression he so vehemently opposed remain potent today. The residue of Stalinism survives in some countries, while others have become tyrannies where personality cults can flourish. Political doublethink still exists. The very fact that the adjective "Orwellian" remains current in English, and that his metaphors have entered mainstream discourse, are further indications that his work remains important. Far from being a writer of the 1930s, Orwell has been able to transcend both distance and time.

Keywords: Relevance, Satire, Orwellian, Derivative, Universal

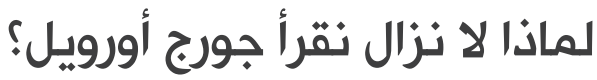

\section{نيل ماكييث}

مستخلص:

تتبنى هذه الورقة مقاربة لدراسة كتابات الكاتب المعروف جورج أورويل من منظور القرن الواحد والعشرين وتطرح التساؤل حول ما

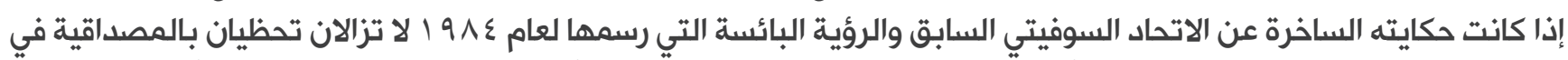

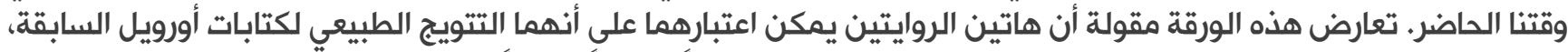

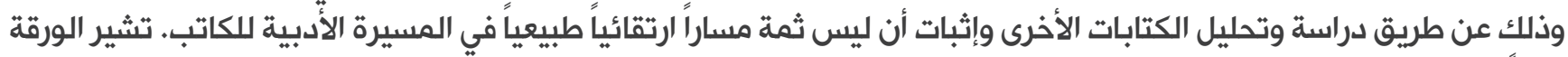

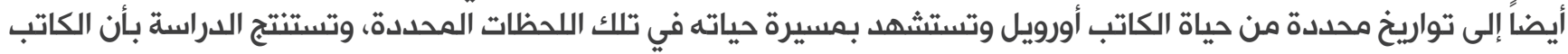

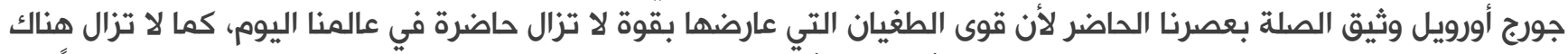

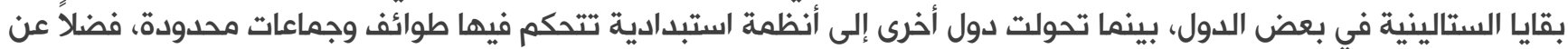

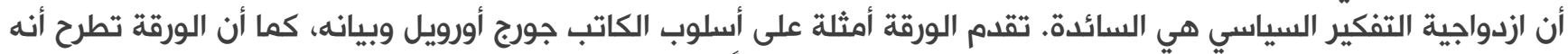

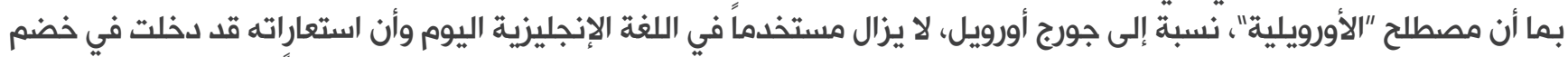

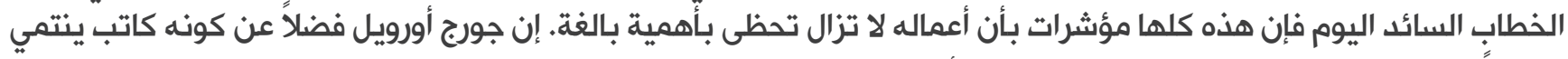

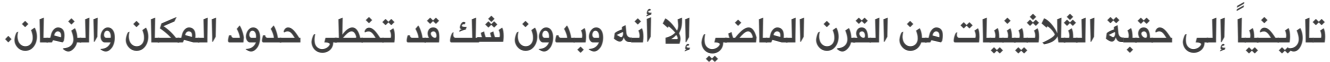




\section{Introduction}

Most would agree that Orwell's fame as a writer rests primarily on his last two novels, Animal Farm (1945) and Nineteen Eighty Four (1948). Yet the year 1984 has come and gone. The date was celebrated by a "plethora of world-wide conferences" (Buitenhuis and Nadel, 1988, p. xi), though discussion at none of them argued that Orwell's dystopian vision was approaching reality. Indeed, since 1990, and the dissolution of the Soviet Union, a tripartite division of the world has become less, rather than more, likely, and what Macey $(1988$, p. 31) describes as "the credibility gap" is wider than ever. The very title of the book has become an anachronism.

Yet the suggestion that Orwell set his book 35 years in the future, knowing "that the price would be the annihilation of his own greatest monument" (Macey) more than overstates the case. The collapse of the Soviet Union has allowed scholars access to classified documentation that proved, if proof were still needed, how close Orwell's satire had come to reality in the Soviet bloc. Montifiore's (2004) account of life in Stalin's Kremlin, and his biography Young Stalin (2008), coupled with Applebaum's (2003) history of the gulag, Service's (2007) history of the communist parties, and even comparatively light journalistic travelogues (Frazier, 2010), have all given the lie to "the belief, shared by many intellectuals, that Marxism is a science, and that we can 'know' thanks to the predictive power of science, that the Marxist creed will ultimately be victorious." (Popper, 1992, pp. 231-232).

Orwell lived in a world where communism could still present itself as a "progressive" force," although that characterization begs the question "progressive in comparison with what?" Animal Farm and Nineteen Eighty-Four both appeared in that narrow window of time between the end of the Second World War and the start of the Cold War. This is significant, because much of Orwell's career is governed by dates.
Important date

In 1980, the Indian polymath Shashi Tharoor went to Huesca in Aragon for the express purpose of drinking a cup of coffee (Tharoor, 2005, p.182)! He did this in homage to George Orwell, who, in 1937 during the Spanish Civil War, fought in a sector of the Aragon front, opposite Huesca. Orwell and his comrades from the Partido Obrero de Unificacion Marxista (POUM) always promised themselves that "Tomorrow we'll have coffee in Huesca" (Tharoor, 2005, p. 183).

Orwell never drank coffee in Huesca. Indeed, he never set foot in the town. On May $20^{\text {th }}, 1937$, a Nationalist sniper shot him through the neck, just under the larynx. Had the bullet been a fraction to the left, he would have been killed instantly, and his name would now be linked with that of the poet John Cornford - as a minor British writer remembered only for the fact that he died in Spain.

\section{Logical fallacy}

Many who work in Orwell studies follow the logical fallacy of post hoc, ergo hoc - the notion that the last two novels were in some way the culmination of his life's enterprise and that all other writings had been leading to this glorious conclusion. In a 1984 panel discussion, Michael Ross maintained said, "I certainly see Orwell's novels as a kind of series that leads up to the best known of his novels" (Buitenhuis and Nadel, 1988, p. 184) although he was immediately contradicted by Orwell's biographer, Bernard Crick, who replied, "I don't see his novels as a series. I see him thrashing around all over the place." (Buitenhuis and Nadel, 1988, p.185).

While financial considerations were also significant, the logical fallacy may also have partly underpinned Sonia Orwell and Ian Angus' (1968) four-volume work The Collected Essays, Journalism and Letters of George Orwell. Their belief appears to have been that no scrap of writing should be omitted, as it might be the key to something greater. 
This suggestion has not lost its power. In an appendix to Taylor's (2004, pp. 432-35) biography of Orwell, there is an analysis of two recently unearthed letters from Orwell to the journalist Malcolm Muggeridge. Had they been bombshells, like Gunter Grass's (2007) admission that he spent the last eight months of the Second World War serving in the Waffen SS, the letters might have been worth reading. As it is, they are both entirely banal.

How Orwell himself would have regarded this gathering of literary relics is, of course, a mystery, but the chances are that he would have rejected it. Much of his 1930s journalism was based on reviewing now forgotten novels, and in the 1940s he worked as a drama critic, arguably the most transient of literary roles. He specifically stated that he did not want A Clergyman's Daughter (1935) or Keep the Aspidistra Flying (1936) to be reprinted. His estate executors ignored these instructions, though in doing so they probably did him no great service. It is also salutary to remember that, had Orwell died outside Huesca in 1937, those two novels would have accounted for half his total output.

\section{The early novels}

Let us briefly examine the novels that appeared between 1933 and 1936. The first, Down and Out in London and Paris (1933) was part novel, part reportage, but from the outset it is clear that it owed an enormous debt to Jack London's (1903) The People of the Abyss. However, precisely because it is so derivative, it lacks the original's impact and of course the conditions Orwell describes are nowhere near as extreme as those witnessed by London. Roberts (1971) explains how the introduction of a non-contributory old age pension scheme in 1909, and the Criminal Justice Administration Act of 1914, instantly reduced the numbers of the truly destitute in England. He also points out that the 1920s was a period of considerable prosperity for the British working class, an era in which their overall standard of living improved to such an extent that many were actually able to save.

Burmese Days (1934) is an oddity. Orwell himself obviously thought quite highly of it, mentioning it, along with Homage to Catalonia (1938), in the preface to the 1947 Ukrainian translation of Animal Farm. By that time, however, the British hold on Burma had been loosened to the point of nominal suzerainty. In the nineteenth century, by contrast, Burma had been so secure, and such a backwater of Empire, that Bahadur Shah Zafar II, India's last Mughal Emperor, was exiled there after the so-called Indian Mutiny (Dalrymple, 2006).

During Orwell's time as a military policeman in Burma, however, imperial prestige took a significant knock when a boycott of British goods forced the authorities to extend the reforms of the 1919 Government of India Act to include the province. The original act had expressly exempted Burma, and so this climb-down was a definite nationalist victory.

By 1947, moreover, the political climate in Burma had been utterly transformed. The Japanese victories of 1942, and the rout of the British, broke the myth of imperial superiority and involved a far greater impact than the British forces' eventual reconquest of the country. Japan's retreating armies, furthermore, abandoned stocks of weaponry that could be used against the returning administration. From the viewpoint of the post-war British government, therefore, granting independence was far easier, and much cheaper, than attempting to reimpose control.

These events of course left Burmese Days as little more than a period piece. Even the extent to which it can be described as an anti-colonial novel is open to dispute. The British at the Kyauktada Club are a deeply unpleasant group, almost a caricature - the club bore, the alcoholic, the cad, the racist bully, the memsahib; the penniless girl of good family who needs a husband. Yet, as Meyers (1991, p. 48) points out "the chief villain is a Burmese, who exploits his people more ruthlessly than the British do." In his determination to be elected as the sole, token, "native" member of the Club, $U$ Po Kyin deliberately sets out to destroy the reputations of 
both Flory and Dr.Veraswami and succeeds. Flory commits suicide and Dr. Veraswami is demoted but to what end? $U$ Po Kyin wins a prize that is effectively worthless.

This returns us to Crick's comment that Orwell was "thrashing about all over the place." Nowhere is this more obvious than in A Clergyman's Daughter. The repressed Dorothy has a mental breakdown, wanders away from the vicarage and its debts, and gets involved with a group of East End Londoners who go down into Kent to pick hops. Returning to London, she becomes briefly destitute before rescue by a distant relative who secures her a place teaching in a terrible little private "school." From there, again, she is rescued and returns to her father's vicarage.

The plot creaks, but allows Orwell to use material left over from Down and Out in London and Paris alongside his own experiences of hopping and suburban school teaching. He stumbles badly when he attempts to employ a sub-Joycean stream of consciousness technique to convey the nightmare quality of a night spent in Trafalgar Square, but ultimately the novel fails because so dated.

After 1939, hopping as it was called disappeared as seasonal casual work and the 1944 Education Act closed down the few remaining private "schools", like Mrs. Creevy's, that had managed to survive the war. Most importantly, however, what Taylor (2004, p. 141) calls the book's "obsession with money" undermines it. Asking the rhetorical question "in what other 1930's novel can one learn the price of a packet of spearmint bouncers or a pound of cheap Danish bacon" (Taylor) begs the second question of why anyone would want to know.

Yet such prices are important. Before starting work at Ringwood House School, Dorothy goes shopping: "She bought herself a ready-made tweed coat and skirt and a jersey to go with them, a hat, and a very cheap frock of artificial printed silk, also a pair of passable brown shoes, three pairs of lisle stockings, a nasty, cheap little handbag, and a pair of grey cotton gloves that would pass for suede at a little distance. That came to eight pounds ten." (Orwell, 1974, p. 172). There are two points here. First, Orwell is clearly lost in the uncharted territory of female psychology. Dorothy is a respectable girl from the middle class and the first item a girl with that background would have purchased would have been new underwear. Second, even allowing for the differences in currency, today Dorothy would be lucky to get even the hat and gloves for eight pounds fifty - and that in a charity shop sale!

The money theme continues in Keep the Aspidistra Flying (1936), where Orwell again draws on his experience, in this instance of working in a bookshop and of trying to live on money from his writing. His unsympathetic, self-pitying antihero, Gordon Comstock, however, has an almost masochistic determination to make himself miserable. Even the coinage of the realm offers him this opportunity. Here he is in full flow against the innocuous threepenny piece, a hexagonal coin introduced in the mid-1930s.

"He had fourpence halfpenny, counting the Joey. But no! The bloody Joey! The girl at the cash desk would titter. In a vivid vision he saw the girl at the cash desk, as he handed her his three-penny bit, grin sidelong at the girl behind the cake counter." (Orwell, 1965, p.77).

Comstock's easiest solution to this terrible dilemma, of course, would have been to change the "Joey" for a more socially acceptable silver threepenny piece, or to change it into three large copper pennies, but instead he must suffer.

The financial theme continues to intrude even on his miserable excursion to the outskirts of London with his girlfriend Rosemary. Walking too far, they get lost and end up paying far more than they can afford for an overpriced lunch at a pretentious, unwelcoming road house-cum-hotel. En route, "they passed huge desolate houses - opulent country houses once, in the carriage days, but now desolate and unsaleable" (Orwell, 1965, p. 77).

Just as in A Clergyman's Daughter, Orwell's accuracy of observation is his own worst enemy. 
Within four years, those same "huge desolate houses" would be requisitioned for the war effort, and by the time of Orwell's death no doubt converted into flats. Clearly, he could not foresee these developments, but neither does the reader of Keep the Aspidistra Flying foresee the utterly false "happy" ending. Reduced to living in a slum boarding house in Lambeth, Comstock gets Rosemary pregnant. Realistically, at this point he would have abandoned her, and she would have either resorted to a back-street abortionist or a home for unmarried mothers. Instead, Gordon surrenders to the "money god" against whom he had constantly railed, resumes work as an advertising copy writer, and marries her.

They celebrate their nuptials at "one of those jolly little Soho restaurants where you can get such a wonderful four-course lunch for half a crown" (Orwell, 1965, p. 257), but here again Orwell's precision has its drawbacks. Penelope Fitzgerald, writing about her cryptographer uncle Alfred Knox, recalls that when he was engaged in deciphering papyri in the British Museum, "he ate in small cafes in Soho....and took the first steps towards the total ruin of his digestion" (Fitzgerald, 2000, p. 98).

\section{Important date -2}

In 1942 - and the date here is imprecise or at least not given by Crick (1980) or Taylor (2004) - Orwell and his wife were invited to dinner by friends who wished to commiserate with their having been recently bombed out of their flat near Baker Street. As they were sitting down to eat, they were literally blown from their seats by a bomb that falling only 50 yards away. The table was covered in splinters of glass from the window, and Eileen Orwell's reaction was "No, no - not again!" Had that bomb killed Orwell that evening, it is still unlikely that he would be much remembered.

\section{The later works}

Yet in the years immediately before the Second World War, Orwell's reputation was growing. He had established himself as a left-wing writer by producing two books of reportage - The Road to Wigan Pier (1937) and Homage to Catalonia (1938). He had also written another novel, Coming up for Air (1939) "which received good notices and did moderately well." (Crick, 1980, p. 254). It would be false, however, to suggest that these three books had any unifying theme. The Road to Wigan Pier was commissioned by the leftwing publisher Victor Gollancz and became a Left Book Club recommendation. Its theme was the desolation that the Great Depression had brought to England's industrial heartland and Wigan was selected because it was among the country's worst affected towns.

Orwell writes trenchantly about the dreadful living conditions in the slums of north-west England and also of the inadequate health and safety provisions made by some employers. One particular passage, on conditions in the coal mines, stands out: "At the larger and better appointed collieries there are pithead baths. This is an enormous advantage, for not only can the miner wash himself all over every day, in comfort and luxury, but at the baths he has two lockers where he can keep his pit clothes separate from his day clothes.... I cannot get hold of exact figures, but it seems likely that less than one miner in three has access to a pithead bath." (Orwell, 197, p. 33).

Again, however, much of what Orwell excoriates was to change within a few years. The nationalization of the coal industry in 1945 ended disparity in conditions between collieries. Moreover, spurred on by the damage done to Britain's housing stock by the Luftwaffe, slum clearance became an immediate postwar priority, with inner city slums giving way to estates of council houses. And, ironically, these reforms were initiated by the post-war Labour government, a government formed by the official Labour Party and in no way influenced by the Independent Labour Party (ILP) to which Orwell belonged. Indeed, it is also interesting that, while the ILP eventually accepted the hopelessness of its own cause, formally disbanding itself in 1974, the POUM - Orwell's other party - was the 
one political grouping in Spain that was never reconstituted after the restoration of democracy in 1977.

This brings us to Homage to Catalonia (1938). Essentially this is a story of the great betrayal, although who betrayed whom is debatable. For the POUM and their anarchist allies it was the betrayal of the revolution by the Spanish Communist Party, which chose to pursue the war against the Nationalists rather than seek radical social change. The opposite side of that coin, of course, is that radical social change was neither desirable nor possible so long as the Civil War was in progress. Either way, there can be no doubt that the Communist Party's decision to follow its orders from Moscow and purge the Republican ranks was entirely counter-productive.

Beevor (2001), however, makes the politically unacceptable point that the eventual Nationalist victory in 1939 was probably the lesser of two evils. It condemned Spain to nearly 30 years of dictatorship; but a Communist Republican victory would have ensured massive reprisals against both the Nationalists and the non-communist Republicans, as well as probably involving Spain in the Second World War (Badcock, 2005). Franco's victory in 1939 at least allowed the country to remain neutral during the later carnage.

Homage to Catalonia, however, is the first book in which Orwell prefigures both Animal Farm and Nineteen Eighty-Four. His experiences of doublethink and political terror found greater expression later on, but the first signs are in this book. Even so, at the time of its release it was not a success. With a refusal from Gollancz, it was published by the smaller left-wing firm of Fred Warburg. On its appearance in April 1938, however, it only sold 800 copies of an original print run of 1500 (Bowker, 2003, p. 237). It came onto a market already saturated with publications about Spain and at a time when Spain was old news because on March $12^{\text {th }} 1938$ the German army had been welcomed into Austria.To add to the book's difficulties, it received exceptionally hostile reviews from The Daily Worker, the mouthpiece of Britain's Communist Party, and it was not until 1968 that it began to sell in any quantity. The 1968 student rising in Paris breathed new life into the Trotskyite left (Marxist, but untainted by Stalin or the Soviet Union), and Orwell's account of Stalinist betrayal was tailor-made for the mood of that time.

The fog of nostalgia that hangs over Coming up for Air (1939) may also have echoed the public's mood in 1939, accounting in part for the novel's initial success. It is, of course, difficult to decide just how much of the nostalgia belongs to Orwell and how much to his protagonist George Bowling, but the book captures something of the Thames Valley in the years immediately prior to the First World War, when Orwell was a child living in Henley-on-Thames. His friend Cyril Connolly, writing of Animal Farm, succinctly summed up the situation: "Mr. Orwell is a revolutionary who is in love with 1910" (Connolly, 1945, quoted in Meyers, 1975, p. 199).

Yet even this novel is derivative. The character of George Bowling owes a great debt to H.G. Wells' Kipps (1905) and The History of Mr. Polly (1910). Orwell's original touch is to make George's marriage to Hilda the stuff of caricature, and particularly the caricature made famous by Donald McGill. In the 1930s, McGill was renowned for producing "saucy" postcards of seaside scenes, frequently featuring a rather stout, red-faced, irresponsible husband and a thin, shrewish wife. Orwell takes this stereotype, and uses it to good effect, though he was not to know that after his death, in 1953, McGill would be convicted of producing "indecent" drawings on the evidence of the same postcards (Travis, 2000). The verdict was hysterical over-reaction to double entendre, but it had the effect of tarnishing McGill's reputation for over a decade.

All this, of course, was in the future. The central difficulty with Coming up for Air is its assumption that war with Germany was inevitable and would start in 1941, whereas it began in September 1939, less than three months after Coming up for Air was published. Attention turned from literature 
and this book is now so little read that even Crick in 1984 mistakenly referred to the hero as "Tom Bowly" (Buitenhuis and Nadel, 1988, p. 185).

\section{Important date - 3}

On April $4^{\text {th }}, 1944$, Victor Gollancz returned the manuscript of Animal Farm to Orwell's agent, stating that although he was "highly critical of many internal and external aspects of Soviet policy" he "could not possibly publish....a general attack of this nature." (Crick, 1980, p. 312).

Following that rejection, the book was offered to Andre Deutsch, who also turned it down, and then to the firm of Jonathon Cape. Cape took advice from an official in the Ministry of Information (identified by Bowker (2003, p. 312) as Peter Smollett, who later turned out to be a Comintern agent). Cape also rejected the book, adding the ludicrous rider that it "would be less offensive if the predominant caste in the fable were not pigs" (Crick, 1980, p. 313)

Orwell then took the book to Faber, where T.S. Eliot rejected it, and finally to Fred Warburg. By October 1944 it was clear that Warburg would publish it and it appeared on the $17^{\text {th }}$ of August 1945. The first edition of 4,500 copies sold out quickly, and a second printing of 10,000 copies followed in November. In America, it was selected by the Book of the Month Club and sold 400,000 copies. It has never been out of print since.

\section{Reflection}

Again, the dates are important. When Gollancz initially rejected Animal Farm, the outcome of the Second World War was still unclear. In April 1944 the Soviet armies had only just recaptured the Crimea and retaken Odessa. The Eastern Front was still in the Soviet Union and the allied advance in Italy was making slow progress. By October 1944, when Warburg accepted Animal Farm, Soviet forces were deep into Poland, France and Belgium had been liberated, and the eventual allied victory was a foregone conclusion. Furthermore, by the time the book was published, the war in Europe had been over for three months and the general public was far less susceptible to propaganda about the Soviet Union, having seen the duplicitous nature of Stalin's policy when the Polish Home Army was left to its fate during the Warsaw Rising (Davies, 2003). British troops and former prisoners of war returning from Germany were also bringing stories of Soviet forces raping and pillaging their way west (MacDonogh, 2007). The mood had changed.

What never changed, on the other hand, was the attitude of the Soviet Union towards Animal Farm. In 1947, a letter to The Daily Worker condemned it as "that anti-Soviet farrago" (Crick, 1981, p. 338). Appropriately, in 1984, Ian Slater attended a conference at Bled in Yugoslavia, where "the business was an attack by the Moscow representative on Orwell's innocence and naivety, which is about the worst thing a Russian can say to you. He also deeply resented the fact that in Animal Farm Orwell characterized all the Soviet people as pigs. He was immediately countered by a Yugoslavian representative who explained at some length that the pigs weren't the Russian people but Stalin and his lieutenants. The Moscow man seemed nonplussed by this, but carried on anyway." (Buitenhuis and Nadel 1988, p. 181.) Meyers (1991, p. 113) reported that "As recently as September 1987, customs officials at the Moscow International Book Fair cleared the British Exhibitors' shelves of Animal Farm. There can be no better certification of its truth."

The question remains, however, whether Animal Farm operates at the level of satire, allegory, or both. Calder (1987, p. 16) rather hedges her bets by describing the book as a "satirical allegory", but Meyers (1991) plumps simply for allegory. According to him, "Manor Farm is Russia, Mr. Jones is the Tsar, the pigs the Bolsheviks who led the revolution" (p. 104) and "Napoleon is Stalin....Snowball is Trotsky...Boxer the carthorse is the decent working man" (p. 105). But even this basic one-for-one interpretation begs further explanation. To begin with, who is the cat, an animal which plays a very peripheral role in farm life, coming and going as she pleases, but fighting 
at the Battle of the Cowshed? Then, also, Tsar Nicholas II was murdered, along with his wife and family; but he has subsequently been canonized as both a saint and martyr by the Russian Orthodox Church. Quite how should we square this tragic figure with Mr. Jones, who dies in an inebriates' home? And what about his wife, who hurriedly exits the farm and is never mentioned again.

Meyers also tells us that "Molly, the unreliable, frivolous mare, represents the White Russians who opposed the revolution and fled the country" (p. 105). At one level she does, but at another her desire for sugar and ribbons, both of which are denied with stern revolutionary fervour by Snowball, could also be interpreted as a desire for more than just the basic Peace, Land, and Bread that the Bolsheviks offered as their slogan in 1917. On this point, Spufford (2010a) is enlightening. It was not until the early 1960s that the Soviet Union succeeded in its aim to "feed, dress, house and educate its people better than Depression America or Nazi Germany" (Spufford, 2010b, p. 26). By that time, of course, the western democracies had moved the target even further away, though Khrushchev, in particular, was unimpressed. In 1959, at the US Trade and Culture Fair in Moscow, he dismissed washing machines and colour TV with the words "Many things you've shown us are interesting, but they are not needed in life. They have no useful purpose. They are merely gadgets" (Service, 2007, p. 361). Snowball could not have put it more clearly.

As for the pigs, it was not until after the war, when Stalin began to appear more frequently alongside the porcine Beria, Khrushchev and Malenkov that the accuracy of Orwell's satire became clear. Since then there have been the jowled Brezhnev, the moon-faced Mao, the dumpy Kim II Sung, and his plump grandson successor Kim Jong Un. And that cast of characters leads us to Nineteen Eighty Four.

\section{Important date - 4}

On the evening of Sunday, December $12^{\text {th }}, 1954$, the $B B C$ broadcast a television adaptation of
Nineteen Eighty Four. It caused such uproar that on Monday $13^{\text {th }}$ December a hastily arranged discussion programme was broadcast, at which critics were able to confront BBC officials. Strong pressure was put on the corporation to cancel a repeat of the dramatization - a repeat that had been scheduled for the evening of Thursday $16^{\text {th }}$. In the end, the $B B C$ refused to give way, and the programme went ahead. This generated yet more complaint and controversy.

\section{Explanation}

Three things must now be explained. First, in 1954 Britain was still a country suffering from collective post-traumatic stress disorder. The Second World War had ended in 1945, but the post-war recovery had taken far longer to accomplish than many had foreseen. Government regulations still exercised control over day-to-day living, and the general consensus of opinion was that the standard of living had declined since the 1930s. In 1954 meat was still rationed. Eighteen-year old men were called up for compulsory National Service. Consumer goods were in short supply and of generally shoddy quality. Reference has already been made to the 1953 censoring of Donald McGill's "naughty" seaside postcards, but in 1954 there was also a list of books that could not be imported into Britain, and BBC radio maintained a list of topics which were off limits as jokes in comedy programmes.

At that time, moreover, the BBC had a total monopoly on television broadcasting in the United Kingdom. There was only one channel, and even that ceased broadcasting at 10:00 pm. It also shut down between 6:00 p.m. and 7:00 pm - the so-called "toddlers' truce", when mothers were supposed to put their small children to bed. This in itself speaks volumes. Effectively, a public corporation had the arrogance to assume that it could intrude into even the most domestic spheres.

Television, however, was still a novelty. Thousands of sets had been bought in 1953, prior to the broadcast of the Coronation, but within the BBC 
itself there were tensions. Designated as a "public service", its higher executives were divided as to whether they ought to offer the public the light entertainment that it appeared to want or whether they should abide by the vision of their first Director General, John Reith, and provide "enlightenment that was middle class, middle brow and middle of the road." (Eldridge, Kitzinger, and Williams, 1997, p. 49.)

Secondly, 1954 was the year when the British postwar religious revival finally flickered out. After 1955 church attendance began to visibly decline, but in 1954 Sunday night viewing was still sabbatarian and definitely family orientated. There was always an early evening religious programme, followed by the toddlers' truce, after which viewers were offered the type of material that could be safely watched by nine-year old children who had led very sheltered lives. Undemanding panel games and Shakespeare, therefore, were acceptable, but a television drama by a comparative unknown like George Orwell was immediately controversial. In this case, moreover, it pushed a dystopian vision of the comparatively near future into the nation's living rooms, and such a vision was not entirely welcome. It made people think. And on a Sunday, too!

The third point concerns the suggestion that Orwell was still comparatively unknown.

"The appearance of Nineteen Eighty Four confirmed Orwell as a major British writer, yet as a novelist he was not particularly well-regarded." (Bowker, 2003, p. 400). As late as 1956, RupertHart Davies said that "Orwell is of no importance from a literary point of view" (Bowker, 2003, p. 424) and the orthodox Communist critics never missed an opportunity to traduce him. By contrast, his obituary in The Times made the perceptive comment that "The death of so searching and sincere a writer is a very real loss." (Bowker, p. 420).

The sales figures for the last two novels partly confirm this. The success of Animal Farm had made Orwell's reputation. That allowed Nineteen Eighty Four to be printed in Britain (July 1948) with an initial print run of 25,500 copies, with two further printings of 5000 copies in March and August 1949. In America, an initial edition of 20,000 copies in June 1948 was followed by further printings of 10,000 copies each in July and August. The Book of the Month Club edition sold 200,000 copies in the next two years, while a Signet paperback sold 750,000 copies in eighteen months.

By 1954, however, sales had slowed. At the time of the BBC broadcast, Nineteen Eighty Four was selling 150 copies a month. In the week after the broadcast, sales figures rocketed to 19,000 . (Lea, 2001, p. 179).

Ironically, therefore, it would appear that the television, as opposed to the telescreen, was the making of Orwell's reputation. The furore generated by the BBC dramatization of his work propelled him into the public consciousness and generated the adjective "Orwellian". His vision became so central to educated thought that his metaphors now pass unnoticed.

Griffiths (2000, p. 46) quotes an officer of the Metropolitan Police explaining, without irony, that his surveillance of ecological protesters is "overpolicing. Zero Tolerance. It's Big Brother." Berlins (2003) uses the title "More Equal than Others" for an article about freedom of expression. In both instances, these are Orwell's own words, used out of context but as appropriate analogies.

Speaking of the Soviet nomenklatura, Service (2007, p. 361) informs us that "Not content to have their snouts in the trough, they had their front trotters there too." In this instance, the metaphor clearly refers to Animal Farm. Yet when Birell (2011, p. 25) describes Sipopo in Equatorial Guinea as "this Orwellian complex" the imagery is ambiguous. In part he refers to the kleptomania of the ruling family: "Sipopo cost four times the annual education budget in what is perhaps the world's most unequal society" (Birell), which takes us back to Animal Farm, but there are also echoes of Nineteen Eighty-Four. Teodoro Obiang, President of Equatorial Guinea, "is lauded on state 
radio as a god in 'permanent contact with the Almighty' who can 'decide to kill without anyone calling him to account and without going to hell."' (Birell, 2011, p. 26).

So why do we still read Orwell?

To begin with, we should admit that we do not. We read some of Orwell's work but we are highly selective and generally restrict ourselves to the last two novels. Those with a deeper interest in Orwell's political thinking may read Homage to Catalonia, but only true enthusiasts go further. Almost nobody reads the essays and journalism. Secondly, many of those who read the last two novels do so for the wrong reasons. Until the late 1970s, it was still possible to read Nineteen EightyFour as if it were some sort of science fiction. It was also possible to ignore the political element of Animal Farm and treat it as a naïve fable. This is the fate that has befallen Gulliver's Travels, which has become a children's book. The satire is ignored, the fantasy remains.

Even so, we should never read Orwell because he is assumed to be undemanding. "Orwell is not a naïve writer: his simplicity is the result of care and deliberation" (Calder, 1987, p. 32-33). Unthinking GCSE examiners, and some EFL teachers, appear to believe that a fable about animals must be easy for students to understand. In fact, the plot of Animal Farm is far more complex than the plots of most Jane Austen novels, where a nice girl meets a nice man. Then there is a problem, but the problem is resolved and they marry.

Neither should we use Orwell's work as a peg on which to hang syntactic and lexical exercises or comprehension exercises that slowly beat the texts to death, concentrating on details and ignoring the author's central themes. Orwell deserves better than that. He wrote for adults, for people with adult political concerns. It does him an injustice to reduce his work to the level of a compulsory school text.

If we read Orwell, therefore, we do so because what he says matters and because his last two novels remain relevant. The mass readership Orwell attracted in the 1940s and early 1950s recognized that a basic truth was reflected in his slightly distorted mirror image of their reality. Animal Farm and Nineteen Eighty-Four took on new relevance as the countries of Eastern Europe metamorphosed into the Warsaw Pact and held their own versions of Soviet show trials to purge heresy from their party ranks.

As readers are aware, after Stalin's death, a succession of other Orwellian tyrants arose across the world, in Eastern Europe, Asia, Africa and Latin America - rulers who concerned only with their person aggrandizement, blind to their own shortcomings, using doublethink, stifling debate by fear and coercion, neglecting the desperate needs of their people for economic and social progress and in one case even inflicting genocide on them.

\section{Conclusion}

So far as Orwell's writings are concerned, therefore, it is clear that we must reject the logical fallacy of "post hoc, ergo propter hoc" examined at the start of this paper. In the last two novels there are occasional echoes from the earlier work, but nothing more. Calder (1987, p. 41) sees a physical similarity between George Bowling and Winston Smith, though Bowling is comparatively prosperous and, if anything, rather too well-fed. Smith is an out-of-condition drudge who survives on unappetizing canteen food. His "golden country" and the bluebell wood on the outskirts of London that he visits with Julia, however, definitely recall the Georgian Thames Valley that held George Bowling in thrall. Animal Farm, moreover, is set in a rural England that still maintains mixed agriculture, with a variety of animals, and plough-horses. Thanks to wartime exigencies, that type of agriculture was still common in the 1940s, but even before the Second World War farmers had experimented with specialization - being exclusively agricultural or raising specific types of stock - beef, poultry, pigs. Orwell ignored this, being "a revolutionary who is in love with 1910".

While Connolly hit the nail on the head, however, 
Rupert Hart-Davies missed his target by a mile. Orwell is of enormous importance "from a literary point of view." His fame has endured long after that of many contemporaries and he cannot be pigeon-holed as a writer of the 1930s. He has a conviction with universal relevance, namely, in Quo's words (1988, p. 135), that "totalitarianism cannot last forever as long as the human spirit exists, though it will triumph somewhere some of the time as long as our flesh is mortal".

\section{References}

Allen, R, 2009, AFTC breaking new ground in English language training for RAFO engineering. Al Kulia, 22-24.

Applebaum, A, 2003, Gulag: A history. New York: Doubleday.

Badcock, J, 2005, Saved by the war. Index on Censorship, 34(2), 68-71.

Beevor, A, 2001, The battle for Spain: The Spanish civil war 1936-39. Harmondsworth: Penguin.

Berlins, M, 2003, More equal than others. Index on Censorship, 32(4), 36-43.

Birrell, I, 2011, Public face of a dictatorship. The Guardian Weekly Review, pp. 25-27.

Bowker, G, 2003, George Orwell. London: Little, Brown.

Buitenhuis, P. and Nadel, I. B, 1988, George Orwell: A reassessment. Basingstoke: Macmillan. Calder, J, 1987, Animal farm and nineteen eightyfour. Milton Keynes: Open University Press.

Crick, B, 1980, George Orwell: A life. London: Secker and Warburg.

Dalrymple, W, 2006, The last Mughal: The fall of a dynasty, Delhi, 1857. London: Bloomsbury.

Davies, N, 2003, Rising '44: The battle for Warsaw. London: Macmillan.

Demick, B, 2010, Nothing left. The New Yorker, July 12 , pp. 44-49.

Demick, B, 2011, Hard to swallow. The Telegraph, October, 36-40.

Eldridge, J, Kitzinger, J, and Williams, K, 1997, The mass media and power in modern Britain. Oxford: Oxford University Press.

Fitzgerald, P, 2000, The Knox Brothers. London:
Flamingo.

Frazier, I, 2010, August 30, On the prison highway: The gulag's silent remains. The New Yorker, 2834.

Grass, G, 2007, June 4, How I spent the war: a recruit in the Waffen SS. The New Yorker, 68-81.

Griffiths, J, 2000, Diary. London Review of Books, 22 (2), 46-47.

Jian, M, 2008, The grand illusion. Index on Censorship, 37(3), 74-78.

King, D, 1999, September, Retouching history. Life, 96-102.

Krzanowski, Mark. (Ed.), 2012, Current developments in English for work and the workplace: Approaches, curricula and materials. Reading: Garnet Publishing.

Lea, D. (Ed.), 2001, George Orwell: Animal farm/ nineteen eighty-four: A reader's guide to essential criticism. Cambridge: Icon Books.

London, J, 1903, The people of the abyss. London: Macmillan.

Macey, S.L, 1988, George Orwell's nineteen eighty-four: The future that becomes the past. In Peter Buitenhuis and Ura B. Nadel. (Eds.).

MacDonogh, G, 2007, After the Reich: From the liberation of Vienna to the Berlin airlift. London: John Murray.

Mattar, H, 2006, In the country of men. London: Viking.

McBeath, N, 2011, Desert island development: Creating ESP courses for Omani Air Force technicians. In Mark Krzanowski. (Ed.), pp. 141152.

Meyers,V, 1991, George Orwell. Basingstoke: Macmillan.

Montifiore, S.S, 2004, The court of the red tsar. New York: Knopf.

Montifiore, S.S, 2008, Young Stalin. New York: Vantage.

Orwell, G, 1933, Down and out in London and Paris. London: Gollancz.

Orwell, G, 1934, Burmese days. London: Gollancz. Orwell, G, 1974, A clergyman's daughter. London: Penguin.

Orwell, G, 1965, Keep the aspidistra flying. 
London: Penguin.

Orwell, G, 1971, The road to Wigan Pier. London: Penguin.

Orwell, G, 1972, Homage to Catalonia. London: Penguin.

Orwell, G, 2000, Animal farm. London: Penguin Classic.

Orwell, G, 1956, Nineteen eighty-four. London. Penguin.

Orwell, S. and Angus, I. (Eds.), 1968, The collected essays, journalism and letters of George Orwell (4 Vols). London: Secker and Warburg.

Popper, K, 1992, Unending quest. London: Routledge.

Roberts, R, 1971, The classic slum: Salford life in the first quarter of the century. Harmondsworth, Penguin.

Quo, F.Q, 1988, Orwell's nineteen eighty-four and Mao's cultural revolution. In P.Buitenhuis and Ira B. Nadel. (Eds.), pp. 126-135.

Service, R, 2007, Comrades: Communism - a world history. London: Pan Macmillan.

Soueif, A. (1992). In the eye of the sun. London: Bloomsbury.

Spufford, F, 2010, Red plenty. London: Faber.

Spufford, F. (2010, September 10). Lessons from a failed utopia. The Guardian Weekly Review, pp. 25- 27.

Taylor, D.J, 2004, Orwell: The life. London: Vintage Books.

Tharoor, S, 2005, Bookless in Baghdad. Delhi, India: Penguin Books.

Travis, A, 2000, Postcard wars. Index on Censorship, 29 (6), 102-105.

Wells, H.G, 1905, Kipps - The story of a simple soul. New York: Scribner.

Wells, H.G, 1910, The history of Mr. Polly. London: Thomas Nelson. 